\section{RSP}

http://www.rsp.fsp.usp.br/
Revista de Saúde Pública

\title{
Effectiveness of antiretroviral therapy in the single-tablet regimen era
}

Juliana de Oliveira Costa', Maria das Graças Braga Ceccato", Micheline Rosa Silveira", Palmira de Fátima Bonolo ${ }^{\mathrm{III}}$, Edna Afonso Reis ${ }^{\mathrm{IV}}$, Francisco de Assis Acurcio ${ }^{\mathrm{l}, \mathrm{II}}$

' Universidade Federal de Minas Gerais. Faculdade de Medicina. Programa de Pós-Graduação em Saúde Pública. Belo Horizonte, MG, Brasil

" Universidade Federal de Minas Gerais. Faculdade de Farmácia. Departamento de Farmácia Social. Belo Horizonte, MG, Brasil

III Universidade Federal de Minas Gerais. Faculdade de Medicina. Departamento de Medicina Preventiva e Social. Belo Horizonte, MG, Brasil

iv Universidade Federal de Minas Gerais. Instituto de Ciências Exatas. Departamento de Estatística. Belo Horizonte, MG, Brasil

\section{ABSTRACT}

OBJECTIVE: To evaluate the effectiveness of antiretroviral therapy and the associated factors according to the type of regimen used: Single Tablet Regimen or Multiple Tablet Regimen.

METHODS: Prospective cohort of 440 patients (male, 74.3\%, median age, 36 years old) who initiated antiretroviral therapy between Jan/14 and Dec/15 at a referral service in Belo Horizonte. Efficacy was defined as viral suppression (viral load, $\mathrm{VL}<50$ copies $/ \mathrm{ml}$ ) and evaluated after six and twelve months of treatment. Sociodemographic, clinical and behavioral data were collected from clinical charts and from Information Systems. Multivariate analysis of overall effectiveness was performed by logistic regression.

RESULTS: Most patients initiated Multiple Tablet Regimen antiretroviral therapy ( $\mathrm{n}=255,58 \%$ ). At six months, overall viral suppression was $74.6 \%$, being higher among patients who used Single Tablet Regimen (80.6\%, $\mathrm{p}=0.04)$. At twelve months, $83.2 \%$ of patients reached viral suppression, with no difference between groups $(\mathrm{p}=0.93)$. Factors independently associated with viral suppression at six and twelve months varied, being negatively associated with effectiveness: VL $\geq 100,000$ copies/ml, symptoms of AIDS, longer interval time between diagnosis and initiation of antiretroviral therapy, antiretroviral switching, smoking or current illicit drugs usage $(\mathrm{p}<0.05)$. Factors positively associated with viral suppression included adherence to antiretroviral therapy and category of risk/exposure of men who have sex with men $(\mathrm{p}<0.05)$. Reaching viral suppression at six months was the main predictor of effectiveness at one year $(\mathrm{OR}=8.96$ and $\mathrm{p}<0.01)$.

CONCLUSIONS: Viral suppression was high and better results were achieved for patients who used Single Tablet Regimen regimens at six months. Clinical, behavioral, and antiretroviral therapy -related factors influence viral suppression and highlight the need for interventions to increase early diagnosis and initiation of antiretroviral therapy, patient's adherence, and to reduce illicit drugs and cigarette smoking in this population.

DESCRIPTORS: Anti-HIV Agents, administration \& dosage. Antiretroviral Therapy, Highly Active. Evaluation of the Efficacy-Effectiveness of Interventions. Cohort Studies.

\footnotetext{
Copyright: This is an open-access article distributed under the terms of the Creative Commons Attribution License, which permits unrestricted use, distribution, and reproduction in any medium, provided that the original author and source are credited.

Juliana de Oliveira Costa

Saúde Pública

Av. Alfredo Balena, 190 Campus Saúde

31130-100 Belo Horizonte, MG, Brasil

Received: Aug 4, 2017

How to cite: Costa JO, Ceccato MGB, Silveira MR, Bonolo PF, Reis antiretroviral therapy in the singletablet regimen era. Rev Saude Publica. 2018;52:87.
} 
a Boletim Epidemiológico de Aids e DST. Brasília (DF): Ministério da Saúde, Secretaria de Vigilância em Saúde; 2016 [cited 2017 Mar 3];5(1).

Available from: http://www.aids. gov.br/pt-br/pub/2016/boletimepidemiologico-de-aids-2016

${ }^{b}$ Ministério da Saúde (BR), Secretaria de Vigilância em Saúde, Departamento de Vigilância, Prevenção e Controle das Infecções Sexualmente Transmissíveis, do HIV/AIDS e das Hepatites Virais. Relatório de monitoramento clínico do HIV. Brasília (DF); 2017. Available from: http://www.aids.gov.br/ pt-br/pub/2017/relatorio-demonitoramento-clinico-do-hiv

cMinistério da Saúde (BR),

Secretaria de Vigilância em Saúde, Departamento de

Vigilância, Prevenção e Controle das Infecções Sexualmente

Transmissíveis, do HIV/AIDS e das Hepatites Virais. Protocolo clínico e diretrizes terapêuticas para manejo da infecção pelo HIV em adultos. Brasília (DF); 2013.

${ }^{d}$ World Health Organization. Consolidated guidelines on the use of antiretroviral drugs for treating and preventing HIV infection: recommendations for a public health approach. 2.ed. Geneva: WHO; 2016 [cited 2017 Apr 20]. Available from: http://www.who. int/hiv/pub/arv/arv-2016/en/

e Ministério da Transparência e Controladoria-Geral da União (BR). Portal da Transparência: gastos diretos do Governo por ação: exercício de 2016. Brasília (DF); 2017 [cited 2017 Mar 3]. Available from: http:// www.transparencia.gov.br/ PortalComprasDiretas

'Ministério da Saúde (BR), Secretaria de Vigilância em Saúde, Programa Nacional de DST e Aids. Critérios de definição de casos de AIDS em adultos e crianças. Brasília (DF); 2004 [cited 2017 Apr 20]. Available from: http://bvsms. saude.gov.br/bvs/publicacoes/ criterios_definicao_AIDS_adultos_ criancas.pdf

${ }^{8}$ World Health Organization. ICD-10: international statistical classification of diseases and related health problems: tenth revision. 2.ed. Geneva: $\mathrm{WHO}$ 2004 [cited 2017 Apr 20]. Available from: http://apps.who. int/iris/handle/10665/42980

\section{INTRODUCTION}

An estimated 830,000 people were living with HIV in Brazil by the end of 2016, a prevalence of $0.4 \%$ in the general population. This prevalence is higher among sex workers, injecting drug users, men who have sex with men (MSM), and persons deprived of liberty ${ }^{\mathrm{a}, \mathrm{b}}$. Of this total, about 498 thousand people use antiretroviral therapy (ART), a coverage rate of $60 \%^{\mathrm{b}}$.

Since 1996, the Brazilian Unified Health System (SUS) has offered ART as part of its care policy for people living with HIV (PLHIV) ${ }^{1}$. Currently, 22 antiretroviral drugs (ARV) are provided for HIV control, including the single-tablet regimen (STR) of tenofovir, lamivudine and efavirenz, listed in $2015^{c}$.

The STR have allowed the simplification of ART and the administration of a single tablet per day compared to multiple-tablet regimens (MTR). The benefits include greater patient preference, increased self-perceived health, greater adherence to ART, greater viral suppression, better laboratory parameters and reduction of associated costs ${ }^{2}$. Thus, several clinical protocols, in agreement with the recommendations of the World Health Organization, favor the use STR as initial therapy ${ }^{2, \mathrm{~d}}$.

The Brazilian Ministry of Health invested over R 1 billion in antiretroviral drugs and the treatment of sexually transmitted diseases in $2016^{e}$. Despite the high investment, studies on the effectiveness of these drugs in Brazil are scarce. Recently published studies ${ }^{3,4}$ are restricted to patients who initiated ART by 2010, when STR were not available and recommendations for initial ART depended on CD4 + T lymphocytes (CD4 + TL) and viral load (VL) levels of patients, as opposed to the current recommendation to initiate treatment promptly, regardless of such parameters ${ }^{\mathrm{c}}$. Added to that is the lack of observational studies in ART-naïve patients who used specifically the STR containing tenofovir, lamivudine and efavirenz.

We aimed to evaluate the effectiveness of antiretroviral drugs in PLHIV according to the type of regimen (STR or MTR) used in the treatment and associated factors.

\section{METHODS}

A non-concurrent prospective cohort of patients who initiated ART between January 2014 and December 2015 at an HIV specialized service (SAE) that provides inpatient and outpatient care in Belo Horizonte, the major point of reference in Minas Gerais.

A total of 1,249 patients were identified in Sistema de Controle Logístico de Medicamentos (Siclom - Logistic Control System of Medicines) and in HIV and AIDS reports issued by the SAE. Of those, 440 met the inclusion criteria (Figure). The following were considered eligible: patients aged 16 or over, diagnosed with HIV, ART-naïve and with at least one outpatient healthcare visit after initiating ART. Pregnant women were excluded due to different therapy indications.

The data were collected from medical records, Siclom and Sistema de Controle de Exames Laboratoriais da Rede Nacional de Contagem de Linfócitos CD4+/CD8+ e Carga Viral (Siscel - Laboratory Examination Control System) The data collected in medical records were: sociodemographic (sex, race, age, marital status, level of education, children, employment); behavioral and lifestyle habits (use of tobacco, alcohol and illicit drugs, prior and during follow-up); clinical/laboratory [possible sources of infection, hospitalizations in the previous year and after initiating ART, initial clinical classification of patient (according to adapted criteria of the Centers for Disease Control and Prevention ${ }^{\mathrm{f}}$ ) and diagnoses of comorbidities and coinfections (according to criteria of the International Classification of Diseases, tenth revision $^{\text {g}}$ )] and drug therapy (time between diagnosis and initial ART; therapy regimen used; record of adverse events; and adherence, characterized by the absence of non-adherence notes in the medical record). 


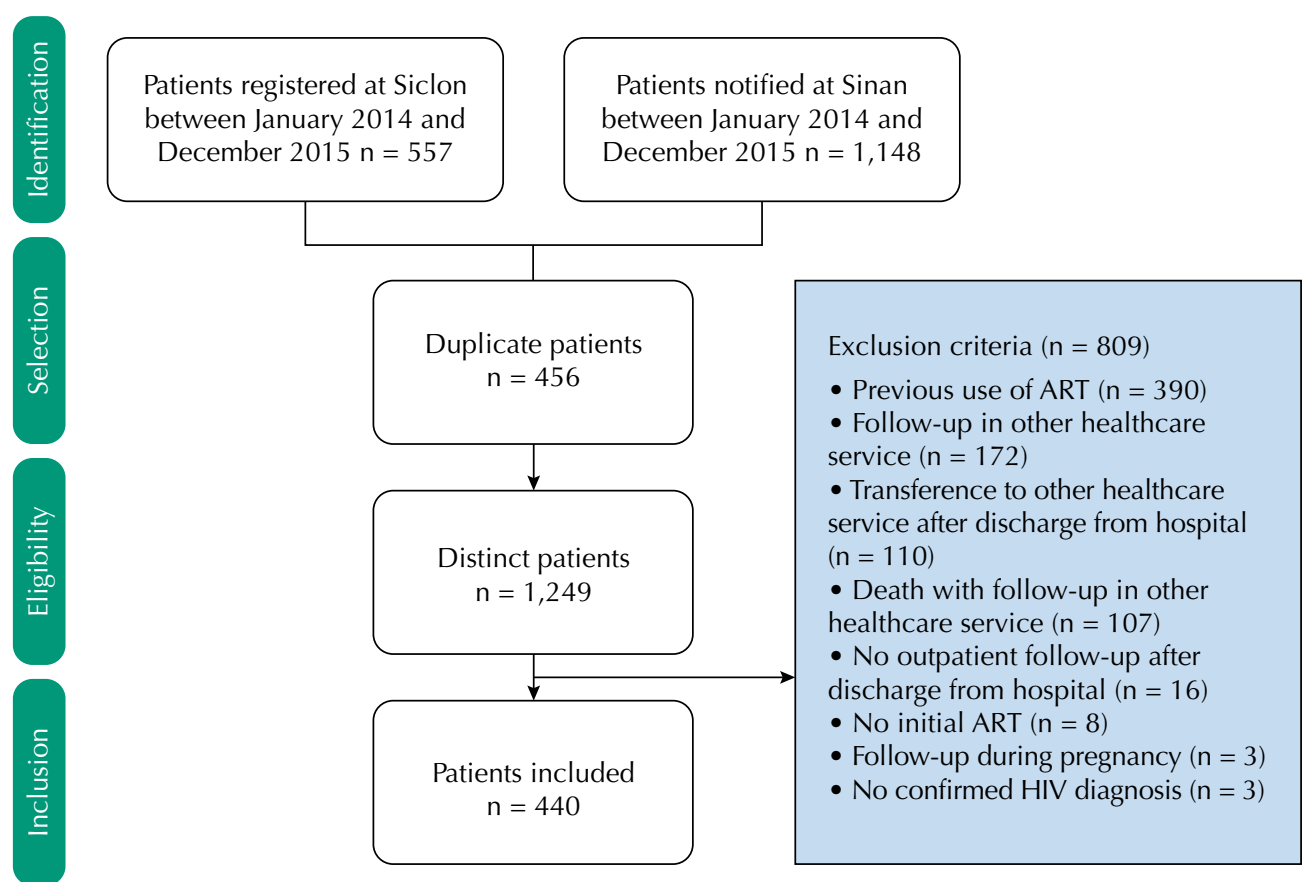

Siclom: Sistema de Controle Logístico de Medicamentos (Logistic Control System of Medicines); Sinan: Sistema de Informação de Agravos de Notificação (Information System for Notifiable Diseases); ART: Antiretroviral therapy

Figure. Diagram of patients' inclusion in the cohort. Belo Horizonte, State of Minas Gerais, 2015.

The ARV switch was collected from Siclom and defined as replacement of an initially prescribed active ingredient. The results of the CD4 + TL and VL counts performed during follow-up were collected from Siscel or, when unavailable, from the patient's medical record.

Data collection was carried out by two trained researchers using a standardized form and typed in EpiInfo ${ }^{\circledR}$ 3.5.4 software. Collection and typing quality was verified by recollecting and retyping $10 \%$ of medical records with Kappa statistic value, indicating perfect interexaminer agreement $(\mathrm{k}=0.92)^{5}$.

Patient follow-up lasted 12 months. The initial date of therapy was determined by the first dispensation of ART to outpatients registered with Siclom or the first dispensation of ART registered in the medical record of patients who began therapy during hospitalization.

Therapy effectiveness was defined as viral suppression (plasma VL $<50$ copies $/ \mathrm{ml}$ ) six months after initial treatment $t^{c}$. Immunological effectiveness and recovery were evaluated as secondary outcomes (increase of more than $30 \%$ of CD $4+$ levels ${ }^{c}$ ) after 12 months of follow-up. A three-month tolerance was used to collect test results to reduce the amount of missing data.

Patients were compared according to initial therapy regimen: STR or MTR. Categorical variables were presented by frequency distribution and quantitative variables by central tendency (mean or median) and variability (SD: standard deviation and TA: total amplitude). The chi-square test was used to compare the groups.

The magnitude of the association between the explanatory variables and effectiveness was estimated by odds ratio with $95 \%$ confidence interval. The independent effect of the explanatory variables was evaluated by a multiple logistic regression model which included all explanatory variables that obtained $\mathrm{p}<0.20$ in the Wald test in simple regression. The goodness of fit of the multiple model was verified by the area under the Receiver Operating Characteristic curve (above 0.7). The level of significance was $5 \%$ for all analyses, performed using R software version 3.4.0. 
Three scenarios were constructed to evaluate the impact of missing data on the analysis outcomes: in the first, only patients with observed data were evaluated; in the second, missing data were considered as success ( $\mathrm{VL}<50$ copies $/ \mathrm{ml}$ ), and, in the third, missing data were considered as failure (VL $\geq 50$ copies $/ \mathrm{ml}$ ).

The missing data were replaced using multiple imputation by chained equations (MICE package, $\mathrm{m}=20)^{6}$. The percentage of missing data was up to $30 \%$ for explanatory variables, and $23.8 \%$ at six months and $22.7 \%$ at 12 months for effectiveness. Imputation consistency was assessed by Pearson correlation between the predicted values of the estimated model using only observed data and data of the imputed model $\left(\mathrm{R}^{2}=0.99\right.$ for six months and $\mathrm{R}^{2}=0.83$ for 12 months). No differential loss was observed between the groups that reached viral suppression or not according to the explanatory variables.

This study is part of the ECOART project "Efetividade da terapia antirretroviral em pessoas vivendo com HIV, HIV/tuberculose, HIV/hanseníase ou HIV/leishmaniose visceral, acompanhados em Belo Horizonte" (Effectiveness of antiretroviral therapy in people living with HIV, HIV/tuberculosis, HIV/leprosy or HIV/visceral leishmaniasis, followed up in Belo Horizonte) approved by the Research Ethics Committee of Universidade Federal de Minas Gerais (CAAE 31192014.3.0000.5149; 2014) and Hospital Eduardo de Menezes (877,392).

\section{RESULTS}

The median follow-up time was 11 months; $22.0 \%$ of patients were hospitalized and 11 died over this period. Most patients were male $(74.3 \%)$ and the main category of risk or exposure to HIV infection was MSM (32.3\%), followed by heterosexual men (30.0\%). Many patients entered the cohort with advanced immunosuppression, characterized by CD4 + counts below 200 cells $/ \mathrm{mm}^{3}$ (32.0\%) and presence of AIDS-defining signs and symptoms (45.7\%), although most had no record of hospitalization due to HIV in the year prior to entering the cohort (52.7\%) (Table 1).

During follow-up, $60.7 \%$ of patients recorded infectious and parasitic diseases, of whom $28.9 \%$ presented HIV complications and $18.2 \%$ infections with a predominantly sexual mode of transmission. Co-infection by tuberculosis and hepatitis B or C occurred in $10.0 \%$ and $2.3 \%$ of the population, respectively. In addition, $25.9 \%$ of patients had a record of mental or behavioral disorder, the most common being depression $(\mathrm{n}=67,15.2 \%)$ and anxiety $(\mathrm{n}=22,5.0 \%)$.

The ART was mainly initiated at outpatient level (63.6\%) with regimens that combined two nucleoside/nucleotide reverse transcriptase inhibitors (NRTI) associated with a non-nucleoside reverse transcriptase inhibitor (NNRTI) (92.0\%) - mainly efavirenz (90.7\%). The most common drug combination was tenofovir, lamivudine and efavirenz (85.0\%), followed by zidovudine, lamivudine and efavirenz (3.6\%). The interval between diagnosis and initial ART was up to 60 days for approximately half of patients (52.5\%), with an average of 1.1 years $(\mathrm{SD}=2.7 ; \mathrm{TA}=21)$. Adherence to treatment was higher in the first six months, $83.4 \%$ of patients, versus $73.4 \%$ at 12 months. At least one incident ART-related adverse reaction was recorded for $50.9 \%$ of patients and ARV switch for $23.9 \%$. The use of illicit drugs and tobacco reduced after initial ART (Table 1).

The distribution of patients in the STR and MTR groups was mostly similar regarding sociodemographic, clinical, ART-related and behavioral and lifestyle characteristics. However, compared to the MTR group, patients who used STR had a higher level of education, fewer were browns, had a lower prevalence of mental disorders, more recent HIV diagnosis, and lower incidence of adverse reactions to ART and ARV switch $(\mathrm{p}<0.05)$ (Table 1).

Viral suppression was observed for $74.6 \%$ of patients at six months of follow-up, and this percentage was higher among patients in the STR group $(\mathrm{p}=0.035)$. Viral suppression 
Table 1. Characteristics of patients included in the study. Belo Horizonte, State of Minas Gerais, 2015. $(n=440)$

\begin{tabular}{|c|c|c|c|c|c|c|}
\hline \multirow{2}{*}{ Variable } & \multicolumn{2}{|c|}{ Total $(n=440)$} & \multicolumn{2}{|c|}{ STR $(n=185)$} & \multicolumn{2}{|c|}{ MTR $(n=255)$} \\
\hline & $\mathbf{n}$ & $\%$ & $\mathbf{n}$ & $\%$ & $\mathbf{n}$ & $\%$ \\
\hline \multicolumn{7}{|c|}{ Sociodemographic } \\
\hline \multicolumn{7}{|l|}{ Sex } \\
\hline Female & 113 & 25.7 & 43 & 23.2 & 70 & 27.5 \\
\hline Male & 327 & 74.3 & 142 & 76.8 & 185 & 72.5 \\
\hline \multicolumn{7}{|l|}{ Age (years) } \\
\hline 16 to 36 & 218 & 49.5 & 91 & 49.2 & 127 & 49.8 \\
\hline$>36$ to 77 & 222 & 50.5 & 94 & 50.8 & 128 & 50.2 \\
\hline \multicolumn{7}{|l|}{ Level of education } \\
\hline Secondary or higher education & 194 & 44.1 & 97 & $52.4^{a}$ & 97 & 38.0 \\
\hline Illiterate to complete primary education & 175 & 39.8 & 65 & 35.1 & 110 & 43.1 \\
\hline Missing data & 71 & 16.1 & 23 & 12.4 & 48 & 18.8 \\
\hline \multicolumn{7}{|l|}{ Race/skin color } \\
\hline Non-brown & 163 & 37.0 & 84 & $45.4^{a}$ & 79 & 31.0 \\
\hline Brown & 272 & 61.8 & 99 & 53.5 & 173 & 67.8 \\
\hline Missing data & 5 & 1.1 & 2 & 1.1 & 3 & 1.2 \\
\hline \multicolumn{7}{|l|}{ Marital status } \\
\hline Married/Stable union & 128 & 29.1 & 54 & 29.2 & 74 & 29.0 \\
\hline Divorced/Single/Widowed & 310 & 70.5 & 130 & 70.3 & 180 & 70.6 \\
\hline Missing data & 2 & 0.5 & 1 & 0.5 & 1 & 0.4 \\
\hline \multicolumn{7}{|l|}{ Employment } \\
\hline Yes & 224 & 50.9 & 90 & 48.6 & 134 & 52.5 \\
\hline No & 182 & 41.4 & 76 & 41.1 & 106 & 41.6 \\
\hline Missing data & 34 & 7.7 & 19 & 10.3 & 15 & 5.9 \\
\hline \multicolumn{7}{|l|}{ Children } \\
\hline Yes & 204 & 46.4 & 86 & 46.5 & 118 & 46.3 \\
\hline No & 190 & 43.2 & 76 & 41.1 & 114 & 44.7 \\
\hline Missing data & 46 & 10.5 & 23 & 12.4 & 23 & 9.0 \\
\hline \multicolumn{7}{|c|}{ Clinical/Laboratory } \\
\hline \multicolumn{7}{|l|}{ Risk/Exposure category } \\
\hline Heterosexual female & 100 & 22.7 & 36 & 19.5 & 64 & 25.1 \\
\hline Heterosexual male & 132 & 30.0 & 56 & 30.3 & 76 & 29.8 \\
\hline MSM & 142 & 32.3 & 57 & 30.8 & 85 & 33.3 \\
\hline Injecting drugs/Other & 13 & 3.0 & 6 & 3.2 & 7 & 2.7 \\
\hline Missing data & 53 & 12.0 & 30 & 16.2 & 23 & 9.0 \\
\hline \multicolumn{7}{|l|}{ Viral load before ART } \\
\hline Up to 100,000 copies/ml & 179 & 40.7 & 88 & 47.6 & 91 & 35.7 \\
\hline$>100,000$ copies $/ \mathrm{ml}$ & 129 & 29.3 & 51 & 27.6 & 78 & 30.6 \\
\hline Missing data & 132 & 30.0 & 46 & 24.9 & 86 & 33.7 \\
\hline CD4+ before ART & & & & & & \\
\hline$>500$ cells $/ \mathrm{mm}^{3}$ & 77 & 17.5 & 33 & 17.8 & 44 & 17.3 \\
\hline 201 to 499 cells $/ \mathrm{mm}^{3}$ & 98 & 22.3 & 37 & 20.0 & 61 & 23.9 \\
\hline Up to 200 cells $/ \mathrm{mm}^{3}$ & 141 & 32.0 & 65 & 35.1 & 76 & 29.8 \\
\hline Missing data & 124 & 28.2 & 50 & 27.0 & 74 & 29.0 \\
\hline Medical condition ${ }^{c}$ & & & & & & \\
\hline With AIDS (C) & 201 & 45.7 & 82 & 44.3 & 119 & 46.7 \\
\hline Without AIDS (A/B) & 239 & 54.3 & 103 & 55.7 & 136 & 53.3 \\
\hline Hospitalizations in previous year & & & & & & \\
\hline 0 & 232 & 52.7 & 104 & 56.2 & 128 & 50.2 \\
\hline 1 & 156 & 35.5 & 56 & 30.3 & 100 & 39.2 \\
\hline 2 or more & 52 & 11.8 & 25 & 13.5 & 27 & 10.6 \\
\hline Hospitalizations during follow-up & & & & & & \\
\hline 0 & 343 & 78 & 147 & 79.5 & 196 & 76.9 \\
\hline 1 & 77 & 17.5 & 29 & 15.7 & 48 & 18.8 \\
\hline 2 or more & 20 & 4.5 & 9 & 4.9 & 11 & 4.3 \\
\hline Hepatitis B or C during follow-up & & & & & & \\
\hline Yes & 10 & 2.3 & 6 & 3.2 & 4 & 1.6 \\
\hline No & 430 & 97.7 & 179 & 96.8 & 251 & 98.4 \\
\hline Mental disorder during follow-up & & & & & & \\
\hline Yes & 114 & 25.9 & 34 & $18.4^{\mathrm{a}}$ & 80 & 31.4 \\
\hline No & 326 & 74.1 & 151 & 81.6 & 175 & 68.6 \\
\hline
\end{tabular}


Table 1. Characteristics of patients included in the study. Belo Horizonte, State of Minas Gerais, 2015. $(\mathrm{n}=440)$. Continuation

\begin{tabular}{|c|c|c|c|c|c|c|}
\hline \multicolumn{7}{|c|}{ ART-related } \\
\hline \multicolumn{7}{|l|}{ Initial treatment } \\
\hline Outpatient unit & 280 & 63.6 & 126 & 68.1 & 154 & 60.4 \\
\hline Hospital & 160 & 36.4 & 59 & 31.9 & 101 & 39.6 \\
\hline \multicolumn{7}{|l|}{ Year } \\
\hline 2014 & 210 & 47.7 & - & - & 210 & 82.4 \\
\hline 2015 & 230 & 52.3 & 185 & 100 & 45 & 17.6 \\
\hline \multicolumn{7}{|c|}{ Initial ART regimen (2 NRTI) } \\
\hline INI & 1 & 0.2 & - & - & 1 & 0.4 \\
\hline $\mathrm{PI}$ & 34 & 7.7 & - & - & 34 & 13.3 \\
\hline NNRTI & 405 & 92 & 185 & 100 & 220 & 86.3 \\
\hline \multicolumn{7}{|c|}{ Time between diagnosis and ART } \\
\hline Up to 2 months & 231 & 52.5 & 108 & $58.4^{\mathrm{a}}$ & 123 & 48.2 \\
\hline$>2$ months & 209 & 47.5 & 77 & 41.6 & 132 & 51.8 \\
\hline \multicolumn{7}{|c|}{ Record of AR to ART during follow-up } \\
\hline Yes & 224 & 50.9 & 65 & $35.1^{\mathrm{a}}$ & 159 & 62.4 \\
\hline No & 216 & 49.1 & 120 & 64.9 & 96 & 37.6 \\
\hline \multicolumn{7}{|c|}{ ARV switch during follow-up } \\
\hline Yes & 105 & 23.9 & 28 & $15.1^{\mathrm{a}}$ & 77 & 30.2 \\
\hline No & 335 & 76.1 & 157 & 84.9 & 178 & 69.8 \\
\hline \multicolumn{7}{|c|}{ Record of adherence to ART in 6 months } \\
\hline Yes & 367 & 83.4 & 158 & 85.4 & 209 & 82 \\
\hline No & 73 & 16.6 & 27 & 14.6 & 46 & 18 \\
\hline \multicolumn{7}{|c|}{ Record of adherence to ART in 12 months } \\
\hline Yes & 323 & 73.4 & 140 & 75.7 & 183 & 71.8 \\
\hline No & 117 & 26.6 & 45 & 24.3 & 72 & 28.2 \\
\hline \multicolumn{7}{|c|}{ Behavioral and lifestyle } \\
\hline \multicolumn{7}{|c|}{ Previous tobacco use } \\
\hline Yes & 223 & 50.7 & 98 & 53.0 & 125 & 49.0 \\
\hline No & 132 & 30.0 & 61 & 33.0 & 71 & 27.8 \\
\hline Missing data & 85 & 19.3 & 26 & 14.1 & 59 & 23.1 \\
\hline \multicolumn{7}{|l|}{ Previous alcohol use } \\
\hline Yes & 288 & 65.5 & 136 & 73.5 & 152 & 59.6 \\
\hline No & 67 & 15.2 & 28 & 15.1 & 39 & 15.3 \\
\hline Missing data & 85 & 19.3 & 21 & 11.4 & 64 & 25.1 \\
\hline \multicolumn{7}{|c|}{ Previous illicit drugs use } \\
\hline Yes & 142 & 32.3 & 76 & 41.1 & 66 & 25.9 \\
\hline No & 179 & 40.7 & 82 & 44.3 & 97 & 38.0 \\
\hline Missing data & 119 & 27.0 & 27 & 14.6 & 92 & 36.1 \\
\hline \multicolumn{7}{|c|}{ Tobacco use during follow-up } \\
\hline Yes & 148 & 33.6 & 59 & 31.9 & 89 & 34.9 \\
\hline No & 264 & 60.0 & 114 & 61.6 & 150 & 58.8 \\
\hline Missing data & 28 & 6.4 & 12 & 6.5 & 16 & 6.3 \\
\hline \multicolumn{7}{|c|}{ Alcohol use during follow-up } \\
\hline Yes & 202 & 45.9 & 90 & 48.6 & 112 & 43.9 \\
\hline No & 204 & 46.4 & 81 & 43.8 & 123 & 48.2 \\
\hline Missing data & 34 & 7.7 & 14 & 7.6 & 20 & 7.8 \\
\hline \multicolumn{7}{|c|}{ Illicit drugs use during follow-up } \\
\hline Yes & 71 & 16.1 & 35 & 18.9 & 36 & 14.1 \\
\hline No & 302 & 68.6 & 123 & 66.5 & 179 & 70.2 \\
\hline Missing data & 67 & 15.2 & 27 & 14.6 & 40 & 15.7 \\
\hline
\end{tabular}

STR: single-tablet regimen; CD4+: CD4+T lymphocites; MSM: men who have sex with men; MTR: multiple-tablet regimen; INI: integrase inhibitors; PI: protease inhibitors; NRTI: nucleoside/nucleotide reverse transcriptase inhibitors; NNRTI: non-nucleoside reverse transcriptase inhibitor; AR: adverse reaction; ARV: antiretroviral drug; ART: antiretroviral therapy

a $\mathrm{p}<0.05$ in the chi-square test for observed data.

${ }^{\mathrm{b}}$ Replacement of an initially prescribed active ingredient by another.

${ }^{c}$ Clinical classification according to adapted criteria of Centers for Disease Control and Prevention;

A: asymptomatic, B: symptomatic, C: AIDS-defining symptoms. 
results in the other scenarios followed the same trend, although statistical significance was observed only in the success scenario (Table 2).

At 12 months of follow-up, $83.2 \%$ of the patients reached viral suppression, with no statistically significant difference between the STR and MTR groups $(p=0.929)$ in all proposed scenarios. In this period, $75.2 \%$ of patients reached immunological recovery, also without differences between the groups. However, the percentage of missing data for this outcome was high (53.2\%), which may compromise the interpretation of results in the proposed scenarios (Table 2).

Bivariate analysis with imputed data showed different factors associated with viral suppression at six and 12 months. Sociodemographic characteristics did not influence the outcome, whereas clinical variables related to disease progression and immunosuppression at the baseline were associated with lower effectiveness: presence of AIDS-defining signs and symptoms and hospitalization records in the year prior to entry into the cohort and viral load above of 100,000 copies/ml for effectiveness at six and 12 months $(\mathrm{p}<0.05)$ (Table 3).

Among ART-related characteristics, antiretroviral drug switch was negatively associated with effectiveness at six and 12 months, while adherence was positively associated with effectiveness in both periods ( $\mathrm{p}<0.05)$. At six months, initiating treatment during hospitalization and use of MTR were associated with a lower probability of achieving effectiveness ( $<$ 0.05), while initiating therapy in 2015 and diagnostic time above two months increased the likelihood of achieving viral suppression $(p<0.05)$. The extent of viral suppression at six months was strongly associated with achieving effectiveness at 12 months of treatment $(\mathrm{OR}=7.78$ and $\mathrm{p}<0.001)$ (Table 3$)$.

Tobacco use during follow-up was negatively associated with viral suppression, and illicit drug use during follow-up reduced the chance of achieving viral suppression at 12 months $(\mathrm{p}<0.05)$ (Table 3).

Clinical, ART-related, behavioral and lifestyle factors remained in the final model associated with effectiveness in the multiple analysis with imputed data. Viral load above 100,000 copies $/ \mathrm{ml}(\mathrm{p}=0.017)$ and presence of AIDS-defining signs and symptoms ( $\mathrm{p}=$ 0.014 ) were associated with approximately $55.0 \%$ and $70.0 \%$ less likelihood of achieving viral suppression at six months, as were ARV switch $(\mathrm{p}<0.001)$ and tobacco use during

Table 2. Effectivity results according to follow-up time and evaluated scenario. Belo Horizonte, State of Minas Gerais, 2015. $(n=440)$

\begin{tabular}{|c|c|c|c|c|c|c|}
\hline \multirow{2}{*}{ Effectiveness rate } & \multicolumn{2}{|c|}{ Overall $(n=440)$} & \multicolumn{2}{|c|}{ STR $(n=185)$} & \multicolumn{2}{|c|}{$\operatorname{MTR}(n=255)$} \\
\hline & $\mathbf{n}$ & $\%$ & $\mathbf{n}$ & $\%$ & $\mathbf{n}$ & $\%$ \\
\hline \multicolumn{7}{|c|}{6 months } \\
\hline \multicolumn{7}{|l|}{ Viral load } \\
\hline Observed data & $250 / 335$ & 74.6 & $112 / 139$ & $80.6^{*}$ & $138 / 196$ & 70.4 \\
\hline Success scenario & $355 / 440$ & 80.7 & $158 / 185$ & $85.4^{*}$ & $197 / 255$ & 77.3 \\
\hline Failure scenario & $250 / 440$ & 56.8 & $112 / 185$ & 60.5 & $138 / 255$ & 54.1 \\
\hline \multicolumn{7}{|c|}{12 months } \\
\hline \multicolumn{7}{|l|}{ Viral load } \\
\hline Observed data & $283 / 340$ & 83.2 & $116 / 139$ & 83.5 & $167 / 201$ & 83.1 \\
\hline Success scenario & $383 / 440$ & 87.0 & $162 / 185$ & 87.6 & $221 / 255$ & 86.7 \\
\hline Failure scenario & $283 / 440$ & 64.3 & $116 / 185$ & 62.7 & $167 / 255$ & 65.5 \\
\hline \multicolumn{7}{|c|}{ Immunological recovery } \\
\hline Observed data & $155 / 206$ & 75.2 & $54 / 67$ & 80.6 & $101 / 139$ & 72.7 \\
\hline Success scenario & $389 / 440$ & 88.4 & $172 / 185$ & $93.0^{*}$ & $217 / 255$ & 85.1 \\
\hline Failure scenario & $155 / 440$ & 35.2 & $54 / 185$ & $29.2^{*}$ & $101 / 255$ & 39.6 \\
\hline
\end{tabular}

STR: single-tablet regimen; MTR: multiple-tablet regimen

$* p<0.05$ in the chi-square test.

Observed data: patients who presented observed data; Success scenario: all missing data are considered success; Failure scenario: all missing data are considered failure. 
follow-up ( $\mathrm{p}=0.005)$. Only adherence to ART increased the chance of achieving viral suppression $(\mathrm{OR}=2.11, \mathrm{p}=0.029)($ Table 4$)$.

The multiple model with imputed data showed that achieving viral suppression at six months was the main predictor of effectiveness at 12 months $(\mathrm{OR}=8.96, \mathrm{p}<0.001)$. In addition, adherence to ART at 12 months and belonging to the MSM category increased the likelihood of achieving viral suppression ( $\mathrm{p}<0.05)$, while use of illicit drugs during follow-up reduced that likelihood by $66.0 \%$ (Table 4).

Table 3. Bivariate analysis of effectiveness evaluated by viral suppression according to follow-up time and patients' characteristics. Belo Horizonte, State of Minas Gerais, 2015. $(n=440)$

\begin{tabular}{|c|c|c|c|c|c|c|}
\hline \multirow{2}{*}{ Variable } & \multicolumn{3}{|c|}{6 months } & \multicolumn{3}{|c|}{12 months } \\
\hline & OR & $95 \% \mathrm{Cl}$ & $\mathbf{p}$ & OR & $95 \% \mathrm{Cl}$ & $\mathbf{p}$ \\
\hline \multicolumn{7}{|c|}{ Sociodemographic } \\
\hline Sex (male) & 0.62 & $0.34-1.12$ & 0.115 & 0.61 & $0.30-1.18$ & 0.159 \\
\hline Age (> 36 years) & 0.83 & $0.51-1.37$ & 0.474 & 1.33 & $0.75-2.36$ & 0.333 \\
\hline Level of education (up to complete primary) & 0.78 & $0.48-1.27$ & 0.314 & 0.97 & $0.56-1.67$ & 0.900 \\
\hline Race/Skin color (brown) & 0.62 & $0.38-1.02$ & 0.060 & 1.10 & $0.60-2.00$ & 0.763 \\
\hline Marital status (single, divorced, widowed) & 1.03 & $0.62-1.71$ & 0.912 & 1.26 & $0.69-2.31$ & 0.451 \\
\hline Employment (no) & 1.23 & $0.72-2.08$ & 0.445 & 1.46 & $0.81-2.64$ & 0.203 \\
\hline Children (yes) & 0.88 & $0.53-1.47$ & 0.626 & 0.71 & $0.40-1.27$ & 0.245 \\
\hline \multicolumn{7}{|c|}{ Clinical } \\
\hline HIV Risk/Exposure (MSM versus heterosexuals, IDU, others) & 1.00 & $0.58-1.72$ & 0.992 & 1.59 & $0.80-3.16$ & 0.183 \\
\hline Viral load before ART (> 100,000 copies/ml) & 0.35 & $0.19-0.65$ & 0.001 & 0.54 & $0.32-0.94$ & 0.030 \\
\hline AIDS $^{a}$ (yes) & 0.27 & $0.16-0.46$ & 0.000 & 0.57 & $0.32-1.01$ & 0.053 \\
\hline Hepatitis B or C (yes) & 0.50 & $0.14-1.81$ & 0.289 & - & - & 0.999 \\
\hline Mental disorder (yes) & 0.63 & $0.37-1.10$ & 0.101 & 0.61 & $0.33-1.12$ & 0.108 \\
\hline Hospitalization in previous year (yes) & 0.45 & $0.27-0.75$ & 0.002 & 0.87 & $0.49-1.53$ & 0.625 \\
\hline Hospitalization during follow-up (yes) & 0.72 & $0.40-1.27$ & 0.255 & 1.01 & $0.49-2.07$ & 0.981 \\
\hline \multicolumn{7}{|c|}{ ART-related } \\
\hline Initial treatment (hospital level) & 0.40 & $0.24-0.66$ & 0.000 & 0.91 & $0.50-1.64$ & 0.749 \\
\hline Initial year of treatment (2015) & 1.73 & $1.05-2.85$ & 0.030 & 1.00 & $0.57-1.77$ & 0.999 \\
\hline Initial ART regimen (PI versus NNRTI) & 0.70 & $0.29-1.69$ & 0.431 & 0.68 & $0.26-1.77$ & 0.431 \\
\hline Initial ART regimen (MTR) & 0.57 & $0.34-0.97$ & 0.036 & 0.97 & $0.55-1.74$ & 0.929 \\
\hline Time between diagnosis and ART ( $>2$ months) & 1.70 & $1.02-2.84$ & 0.043 & 0.68 & $0.39-1.21$ & 0.189 \\
\hline Record of AR to ART (yes) & 0.88 & $0.53-1.43$ & 0.597 & 0.99 & $0.56-1.74$ & 0.963 \\
\hline ARV switch ${ }^{b}$ (yes) & 0.24 & $0.14-0.42$ & 0.000 & 0.52 & $0.28-0.95$ & 0.035 \\
\hline Adherence to ART in 6 months (yes) & 2.28 & $1.25-4.14$ & 0.007 & - & - & - \\
\hline Adherence to ART in 12 months (yes) & - & - & - & 4.04 & $2.24-7.31$ & 0.000 \\
\hline Effectiveness at 6 months (yes) & - & - & - & 7.78 & $3.83-15.78$ & 0.000 \\
\hline \multicolumn{7}{|c|}{ Behavioral and lifestyle } \\
\hline Tobacco use in life (yes) & 0.72 & $0.41-1.28$ & 0.265 & 0.60 & $0.31-1.16$ & 0.127 \\
\hline Alcohol use in life (yes) & 0.86 & $0.46-1.28$ & 0.631 & 0.76 & $0.35-1.67$ & 0.487 \\
\hline Drug use in life (yes) & 0.66 & $0.40-1.06$ & 0.087 & 0.52 & $0.27-1.01$ & 0.053 \\
\hline Recent tobacco use (sim) & 0.49 & $0.31-0.78$ & 0.003 & 0.43 & $0.23-0.80$ & 0.009 \\
\hline Alcohol use during follow-up (yes) & 1.00 & $0.58-1.71$ & 0.991 & 0.75 & $0.41-1.36$ & 0.335 \\
\hline Drug use during follow-up (yes) & 0.66 & $0.34-1.28$ & 0.222 & 0.39 & $0.21-0.73$ & 0.004 \\
\hline
\end{tabular}

CD4+: CD4+T lymphocites; MSM: men who have sex with men; IDU: injecting drug user; MTR: multiple-tablet regimen; PI: protease inhibitors; NNRTI: non-nucleoside reverse transcriptase inhibitor; AR: adverse reaction; ARV: antiretroviral drug; ART: antiretroviral therapy

${ }^{a}$ Clinical classification according to adapted criteria of Centers for Disease Control and Prevention.

${ }^{\mathrm{b}}$ Replacement of an initially prescribed active ingredient by another. 
Table 4. Multivariate analysis of effectiveness evaluated by viral suppression according to follow-up time and patients' characteristics. Belo Horizonte, State of Minas Gerais, 2015. $(n=440)$

\begin{tabular}{|c|c|c|c|c|c|c|}
\hline \multirow{2}{*}{ Variable } & \multicolumn{3}{|c|}{6 months ${ }^{a, b}$} & \multicolumn{3}{|c|}{12 months $^{\mathrm{c}, \mathrm{d}}$} \\
\hline & OR & $95 \% \mathrm{Cl}$ & p & OR & $95 \% \mathrm{Cl}$ & $\mathbf{P}$ \\
\hline \multicolumn{7}{|l|}{ Clinical } \\
\hline HIV risk (MSM versus other groups) & - & - & - & 2.44 & $1.04-5.69$ & 0.040 \\
\hline Viral load before ART (> 100,000 copies/ml) & 0.40 & $0.19-0.84$ & 0.017 & - & - & - \\
\hline AIDS (yes) & 0.47 & $0.26-0.86$ & 0.014 & - & - & - \\
\hline \multicolumn{7}{|l|}{ ART-related } \\
\hline Time between diagnosis and ART (> 2 months) & - & - & - & 0.40 & $0.19-0.84$ & 0.017 \\
\hline ARV switche (yes) & 0.31 & $0.17-0.56$ & 0.000 & - & - & - \\
\hline Adherence to ART in 6 months (yes) & 2.11 & $1.08-4.13$ & 0.029 & - & - & - \\
\hline Adherence to ART in 12 months (yes) & - & - & - & 2.34 & $1.14-4.79$ & 0.020 \\
\hline Effectiveness at 6 months (yes) & - & - & - & 8.96 & $3.98-20.17$ & 0.000 \\
\hline \multicolumn{7}{|l|}{ Behavioral } \\
\hline Recent tobacco use (yes) & 0.45 & $0.26-0.79$ & 0.005 & - & - & - \\
\hline Drug use during follow-up (yes) & - & - & - & 0.34 & $0.15-0.79$ & 0.012 \\
\hline
\end{tabular}

ARV: antiretroviral drug; MSM: men who have sex with men; ART: antiretroviral therapy; ROC: Receiver Operating Characteristic

${ }^{\text {a }}$ Area under ROC curve $=0.785$.

b Pearson coeficiente correlation $\mathrm{R}^{2}=0.99$.

${ }^{c}$ Area under ROC curve $=0.974$.

d Pearson coeficiente correlation $\mathrm{R}^{2}=0.83$.

e Replacement of an initially prescribed active ingredient by another.

\section{DISCUSSION}

In this Brazilian cohort study, which included only ART-naïve patients, the overall effectiveness of antiretroviral therapy was high, $74.6 \%$ at six months and $83.2 \%$ at 12 months of treatment, similar to rates in developed countries ${ }^{7,8}$. The single-tablet regimen with tenofovir, lamivudine and efavirenz was associated with greater viral suppression at six months of treatment compared to multiple-tablet regimens.

The characteristics of the patients included in this study are similar to the profile of PLHIV in Brazil, as published in epidemiological bulletins and other national studies ${ }^{3,4, a}$. Patients were predominantly male, sexually infected and heterosexual. Most patients initiated ART with two NRTI associated with one NNRTI, in accordance with the Clinical Protocol and Therapeutic Guidelines in force at the time ${ }^{c}$.

Overall effectiveness at six months agrees with the results obtained by Cardoso et al. ${ }^{4}$ in a cohort of patients in Rio de Janeiro (76.9\%). At 12 months of follow-up, the result (83.2\%) was slightly higher than those reported in Brazilian studies carried out between 2000 and $2010(76.1 \% \text { and } 77.4 \%)^{3,4}$, and higher than those observed in previous studies, $46.9 \%$ and 48.4\% between 1997 and 2004,10. This difference may reflect the shorter interval between diagnosis and initial therapy, according to changes in initial therapy ${ }^{7, c}$. In addition, the better performance of newer drugs and formulations, which reduce the occurrence of adverse events, provide greater dosage convenience, and require a lower adherence rate to be effective may have contributed to this difference ${ }^{4,11}$.

The simplified therapy regimen with daily ingestion of tablets only once a day is associated with the higher level of adherence of patients to ART and higher levels of viral suppression when using STR or absence of difference between groups ${ }^{2}$. In this cohort, effectiveness results for patients using STR were similar to results published in randomized controlled trials in ART-naïve patients, which reported viral suppression rates between $80 \%$ and $88 \%^{12-14}$, albeit with different regimen compositions.

These results reinforce the strategy of supplying generic drugs in STR in Brazil. Although the difference between groups was not statistically significant at 12 months of follow-up, there was a trend of better results for patients using this drug regarding the incidence of adverse events, switch of therapy regimens, adherence to treatment and immunological recovery, as well as higher viral suppression at six months of ART. 
The effectiveness of antiretroviral therapy was influenced by clinical, behavioral and ART-related factors. Among the factors that predicted effectiveness at six months, initiating treatment with high viral load and AIDS-defining signs and symptoms were negatively associated with viral suppression, as reported in previous studies ${ }^{8,15-17}$. Initiating ART regardless of CD4+ cell counts has been adopted in Brazil since 2013. Recent studies indicate a 50\% reduction in the incidence of serious AIDS-related events, such as death and opportunistic diseases, among patients who initiate ART early $\left(\mathrm{CD} 4+\text { count }>500 \text { cells } / \mathrm{mm}^{3}\right)^{18,19}$. Patients who initiated ART within a shorter interval after diagnosis had a greater chance of achieving viral suppression at 12 months in this study.

Despite knowledge of these benefits and policies introduced to increase access to diagnosis and treatment, such as expansion of testing sites and availability of quick diagnostic tests ${ }^{\mathrm{h}}$, most patients initiated ART with advanced immunosuppression. The same pattern was observed in Brazilian studies in previous years ${ }^{3,20}$ and may be related to difficult access to healthcare services and lack of knowledge and awareness of the population about HIV risks. This results in late search for healthcare services and, consequently, late initiation of $\mathrm{ART}^{20}$.

The MSM were more likely to achieve viral suppression after 12 months of treatment compared to other risk or exposure categories. This result may reflect a greater involvement of those patients in continuous healthcare ${ }^{21}$. However, further studies are needed for inferences in this population.

The ARV switch and ART adherence influenced viral suppression. The ARV switch is associated with lower adherence to treatment and may be more closely related to the occurrence of adverse events and intolerance rather than virologic failure ${ }^{22,23}$. It may also be due to timely monitoring of effectiveness.

The relationship between adherence to treatment and ART effectiveness is well documented in the literature ${ }^{8,10,16}$ and the lowest level of adherence required to ensure the effectiveness of antiretroviral drugs is between $80.0 \%$ and $95.0 \%{ }^{11}$. In this study, non-adherence was observed in the medical records of $16.6 \%$ of patients over six months and $26.6 \%$ over 12 months. Such data are worrying, since medical records underestimate actual non-adherence figures. Non-adherence may lead to the development of viral resistance, progression of the disease, increased morbidity and mortality due to AIDS and contribute to increase patient care costs ${ }^{10,11}$.

Viral suppression at six months was the main predictor of effectiveness in one year ${ }^{16,17}$. No patients in this study had previously used ART. Considering the prevalence of HIV-resistant strains in Brazil $(11.6 \%)^{24}$, failure of viral suppression is probably due to non-adherence, although resistance to NNRTI antiretroviral drugs has increased in Minas Gerais ${ }^{25}$. Checking patients' adherence to therapy and carrying out actions to increase it are as important as timely monitoring of viral load and performance of genotyping tests to ensure adequate response to treatment.

Use of substances such as tobacco and illicit drugs during follow-up were associated with lower likelihood of achieving viral suppression. Tobacco use among PLHIV has been linked to worse clinical outcomes, such as increased viral load, reduced CD4+ cell count and increased occurrence of opportunistic infections ${ }^{26,27}$. The negative impact of tobacco use and its high prevalence in this population evidence the need to enhance non-smoking programs in HIV/AIDS specialized units.

Secretaria de Vigilância em Saúde, Departamento de Vigilância, Prevenção e Controle das IST, do HIV/AIDS e das Hepatites Virais. Relatório de monitoramento clínico do HIV - 2016. Brasília (DF); 2016 [cited 2017 Apr 20]. Available from: http://www.aids gov.br/pt-br/pub/2016/relatoriode-monitoramento-clinico-dohiv-2016

The use of illicit substances among PLHIV may be related both to the actual source of infection and to diagnosis coping mechanisms ${ }^{28}$. The use of these substances is related to lower levels of adherence to treatment, lower viral suppression and lower levels of $\mathrm{CD} 4+^{28,29}$. Worse results are also reported with previous use of illicit drugs ${ }^{3,29,30}$. Treating chemical dependency, introducing other methods to help cope with the diagnosis and raising the health team's awareness of the problem $^{28-30}$ are possible strategies to improve the clinical results of these patients. 
This study has limitations, such as poor accuracy of measurements collected from medical records and high percentage of missing data. The strategies used to minimize their effect were the elaboration of clinical scenarios and data imputation, with no change in the trend of results. Study strengths include the high quality of collection, the broad inclusion of confounding factors, and the robustness of the final model in both follow-up periods

The incidence of viral suppression at six and 12 months in patients with no prior use of ART was high, with differences between patients using STR and MTR. Clinical, behavioral, lifestyle, and ART-related factors influenced viral suppression. They also demonstrated the need for interventions to improve diagnosis and the timely initiation of treatment, patients' adherence to therapy, and the reduction of tobacco and illicit drugs use, so as to optimize treatment outcome and contribute to quality of life and reduction of HIV transmission.

\section{REFERENCES}

1. Hallal R, Ravasi G, Kuchenbecker R, Greco D, Simão M. O acesso universal ao tratamento antirretroviral no Brasil. Tempus Actas Saude Coletiva. 2010;4(2):53-66. https://doi.org/10.18569/tempus.v4i2.791

2. Clay PG, Nag S, Graham CM, Narayanan S. Meta-analysis of studies comparing single and multi-tablet fixed dose combination HIV treatment regimens. Medicine (Baltimore). 2015;94(42):e1677. https://doi.org/10.1097/MD.0000000000001677

3. Grangeiro A, Escuder MM, Cassanote AJF, Souza RA, Kalichman AO, Veloso V, et al. The HIV-Brazil Cohort Study: design, methods and participant characteristics. PLoS One. 2014;9(5):e95673. https://doi.org/10.1371/journal.pone.0095673

4. Cardoso SW, Luz PM, Velasque L, Torres T, Coelho L, Freedberg KA, et al. Effectiveness of firstline antiretroviral therapy in the IPEC cohort, Rio de Janeiro, Brazil. AIDS Res Ther. 2014;11:29. https://doi.org/10.1186/1742-6405-11-29

5. Landis JR, Koch GG. The measurement of observer agreement for categorical data. Biometrics. 1977;33(1):159-74. https://doi.org/10.2307/2529310

6. Buuren S, Groothuis-Oudshoorn K. MICE: Multivariate Imputation by Chained Equations in R. J Stat Softw. 2011;45(3). https://doi.org/10.18637/jss.v045.i03

7. Marconi VC, Grandits GA, Weintrob AC, Chun H, Landrum ML, Ganesan A, et al. Outcomes of highly active antiretroviral therapy in the context of universal access to healthcare: the U.S. Military HIV Natural History Study. AIDS Res Ther. 2010;7:14. https://doi.org/10.1186/1742-6405-7-14

8. Elzi L, Erb S, Furrer H, Ledergerber B, Cavassini M, Hirschel B, et al. Choice of initial combination antiretroviral therapy in individuals with HIV infection: determinants and outcomes. Arch Intern Med. 2012;172(17):1313-21. https://doi.org/10.1001/archinternmed.2012.3216

9. Grinsztejn B, Veloso VG, Pilotto JH, Campos DP, Keruly JC, Moore RD. Comparison of clinical response to initial highly active antiretroviral therapy in the patients in clinical care in the United States and Brazil. J Acquir Immune Defic Syndr. 2007;45(5):515-20. https://doi.org/10.1097/QAI.0b013e3180decb6a

10. Acurcio FA, Puig-Junoy J, Bonolo PF, Ceccato MGB, Guimarães MDC. Análisis coste-efectividad de la adhesión inicial a la terapia antirretroviral entre individuos infectados por el VIH en Belo Horizonte, Brasil. Rev Esp Salud Publica. 2006 [cited 2017 Apr 20];80(1):41-54. Available from: http://scielo.isciii.es/pdf/resp/v80n1/original1.pdf

11. Sutton SS, Magagnoli J, Hardin JW. Odds of viral suppression by single-tablet regimens, multiple-tablet regimens, and adherence level in HIV/AIDS patients receiving antiretroviral therapy. Pharmacotherapy. 2017;37(2):204-13. https://doi.org/10.1002/phar.1889

12. Gallant JE, Dejesus E, Arribas JR, Pozniak AL, Gazzard B, Campo RE, et al. Tenofovir DF, emtricitabine, and efavirenz vs. zidovudine, lamivudine, and efavirenz for HIV. N Eng J Med. 2006;354(3):251-60. https://doi.org/10.1056/NEJMoa051871

13. Cohen C, Wohl D, Arribas JR, Henry K, Van Lunzen J, Bloch M, et al. Week 48 results from a randomized clinical trial of rilpivirine/emtricitabine/tenofovir disoproxil fumarate vs. efavirenz/ emtricitabine/tenofovir disoproxil fumarate in treatment-naive HIV-1-infected adults. AIDS. 2014;28(7):989-97. https://doi.org/10.1097/QAD.0000000000000169 
14. Walmsley SL, Antela A, Clumeck N, Duiculescu D, Eberhard A, Gutiérrez F, et al. Dolutegravir plus abacavir-lamivudine for the treatment of HIV-1 infection. N Engl / Med. 2013;369(19):1807-18. https://doi.org/10.1056/NEJMoa1215541

15. Kitchen CM, Kitchen SG, Dubin JA, Gottlieb MS. Initial virological and immunologic response to highly active antiretroviral therapy predicts long-term clinical outcome. Clin Infect Dis. 2001;33(4):466-72. https://doi.org/10.1086/321900

16. Fielding KL, Charalambous S, Stenson AL, Pemba LF, Martin DJ, Wood R, et al. Risk factors for poor virological outcome at 12 months in a workplace-based antiretroviral therapy programme in South Africa: a cohort study. BMC Infect Dis. 2008;8:93. https://doi.org/10.1186/1471-2334-8-93

17. Powderly WG, Saag MS, Chapman S, Yu G, Quart B, Clendeninn NJ. Predictors of optimal virological response to potent antiretroviral therapy. AIDS. 1999;13(14):1873-80. https://doi.org/10.1097/00002030-199910010-00009

18. INSIGHT Initiate Study Group. Initiation of antiretroviral therapy in early asymptomatic HIV infection. N Engl J Med. 2015;379(9):795-807. https://doi.org/1056/NEJMoa1506816

19. TEMPRANO ANRS 12136 Study Group. A trial of early antiretrovirals and isoniazid preventive therapy in Africa. N Engl J Med. 2015;373(9):808-22. https://doi.org/10.1056/NEJMoa1507198

20. Fernandes JRM, Acúrcio FA, Campos LN, Guimarães MDC. Início da terapia antiretroviral em estágio avançado de imunodeficiência entre indivíduos portadores de HIV/ AIDS em Belo Horizonte, Minas Gerais, Brasil. Cad Saude Publica. 2009;25(6):1369-80. https://doi.org/10.1590/S0102-311X2009000600019

21. Burchell AN, Gardner S, Light L, Ellis BM, Antoniou T, Bacon J, et al. Implementation and operational research: engagement in HIV care among persons enrolled in a clinical HIV cohort in Ontario, Canada, 2001-2011. J Acquir Immune Defic Syndr. 2015;70(1):e10-19. https://doi.org/10.1097/QAI.0000000000000690

22. Bonolo PF, César CC, Acúrcio FA, Ceccato MGB, Pádua CAM, Álvares J, et al. Non-adherence among patients initiating antiretroviral therapy: a challenge for health professionals in Brazil. AIDS. 2005;19 Suppl 4:S5-13. https://doi.org/10.1097/01.aids.0000191484.84661.2b

23. Heath KV, Singer J, O'Shaughnessy MV, Montaner JSG, Hogg RS. Intentional nonadherence due to adverse symptoms associated with antiretroviral therapy. I Acquir Immune Defic Syndr. 2002;31(2):211-7. https://doi.org/10.1097/01.QAI.0000026512.98625.08

24. Moraes Soares CMP, Vergara TRC, Brites C, Brito JDU, Grinberg G, Caseiro MM, et al. Prevalence of transmitted HIV-1 antiretroviral resistance among patients initiating antiretroviral therapy in Brazil: a surveillance study using dried blood spots. J Int AIDS Soc. 2014;17(1):19042. https://doi.org/10.7448/IAS.17.1.19042

25. Duani $\mathrm{H}$, Aleixo AW, Tupinambás U. Trends and predictors of HIV-1 acquired drug resistance in Minas Gerais, Brazil: 2002-2012. Braz J Infect Dis. 2017;21(2):148-54. https://doi.org/10.1016/j.bjid.2016.11.009

26. Hile SJ, Feldman MB, Alexy ER, Irvine MK. Recent tobacco smoking is associated with poor HIV medical outcomes among HIV-infected individuals in New York. AIDS Behav. 2016;20(8):1722-9. https://doi.org/10.1007/s10461-015-1273-x

27. Ompad DC, Kingdon M, Kupprat S, Halkitis SN, Storholm ED, Halkitis PN. Smoking and HIVrelated health issues among older HIV-positive gay, bisexual, and other men who have sex with men. Behav Med. 2014;40(3):99-107. https://doi.org/10.1080/08964289.2014.889067

28. Arnsten JH, Demas PA, Grant RW, Gourevitch MN, Farzadegan H, Howard AA, et al. Impact of active drug use on antiretroviral therapy adherence and viral suppression in hiv-infected drug users. J Gen Intern Med. 2002;17(5):377-81. https://doi.org/10.1046/j.1525-1497.2002.10644.x

29. Cofrancesco J Jr, Scherzer R, Tien PC, Gibert CL, Southwell H, Sidney S, et al. Illicit drug use and HIV treatment outcomes in a US cohort. AIDS. 2008;22(3):357-66. https://doi.org/10.1097/QAD.0b013e3282f3cc21

30. Tucker JS, Burnam MA, Sherbourne CD, Kung FY, Gifford AL. Substance use and mental health correlates of nonadherence to antiretroviral medications in a sample of patients with human immunodeficiency virus infection. Am J Med. 2003;114(7):573-80. https://doi.org/10.1016/S0002-9343(03)00093-7 
Funding: Fundação de Amparo à Pesquisa do Estado de Minas Gerais (CDS - APQ-03938-16). JOC received a $\mathrm{PhD}$ grant from Coordenação de Aperfeiçoamento de Pessoal de Nível Superior (CAPES).

Authors' Contribution: Study design and planning: JOC, EAR, MGBC, FAA. Data collection: JOC. Data analysis and interpretation: JOC, PFB, MRS, EAR, MGBC, FAA. Drafting and revision: JOC, PFB, MRS, EAR, MGBC, FAA. All authors approved the final version and take public responsibility for its content.

Acknowledgments: Thanks to the staff at Hospital Eduardo de Menezes and Projeto ECOART, especially Romara Elizeu Amaro Perdigão and Bianca Magda Lopes de Freitas, for the help in data collection, and Jéssica Luiza Ferreira Ramos, for the contribution in statistical analyses.

Conflict of Interest: The authors declare no conflict of interest. 